\title{
Atrial fibrillation patients who sustained warfarin-associated intracerebral haemorrhage have poor neurological outcomes: results from a matched case series
}

\author{
MK Fong *, B Sheng, YP Chu, WT Wong, Patrick PK Lau, HY Wong, KK Lau
}

\section{A B S T R A C T}

Introduction: Coagulopathy-associated intracerebral haemorrhage has become increasingly common because of the rising demand in the ageing population for anticoagulation for atrial fibrillation. This study compared the clinical features and neurological outcomes of intracerebral haemorrhage in patients with atrial fibrillation who were prescribed warfarin with those who were not.

Methods: This was a retrospective matched case series of patients with intracerebral haemorrhage from three tertiary hospitals in Hong Kong from 1 January 2006 to 31 December 2011. Patients who developed intracerebral haemorrhage and who were prescribed warfarin for atrial fibrillation (ICH-W group) were compared with those with intracerebral haemorrhage and not prescribed warfarin ( $\mathrm{ICH}-\mathrm{C}$ group); they were matched for age and gender in 1:1 ratio. Clinical features and neurological outcomes were compared, and the impact of coagulopathy on haematoma size was also studied.

Results: We identified 114 patients in the ICH-W group with a mean age of 75 years. Both $\mathrm{ICH}-\mathrm{W}$ and $\mathrm{ICH}-\mathrm{C}$ groups had a median intracerebral haemorrhage score of 2 . There was a non-statistically significant trend of higher intracerebral haemorrhage volume in the ICH-W group (12.9 mL vs $10.5 \mathrm{~mL}$ ). The

This article was published on $24 \mathrm{Feb}$ 2017 at www.hkmj.org. median modified Rankin Scale and the proportion with good recovery (modified Rankin Scale score $\leq 3$ ) at 6 months were comparable. Nonetheless, ICH-W patients had higher hospital mortality $(51.8 \%$ vs $36.0 \% ; \mathrm{P}=0.02)$ and 6 -month mortality $(60.5 \%$ vs $43.0 \% ; \mathrm{P}=0.01)$ than $\mathrm{ICH}-\mathrm{C}$ patients. Overall, $60 \%$ of ICH-W patients had their admission international normalised ratio within the therapeutic range during intracerebral haemorrhage, and $14 \%$ had a subtherapeutic admission international normalised ratio. International normalised ratio at admission was not associated with intracerebral haemorrhage volume or neurological outcome.

Conclusion: Warfarin-associated intracerebral haemorrhage in patients with atrial fibrillation carried a higher stroke mortality than the nonwarfarinised patients.

\section{Hong Kong Med J 2017;23:117-21}

DOI: $10.12809 / \mathrm{hkmj} 164953$
MK Fong *, MB, BS, FHKAM (Medicine)
'B Sheng, MB, ChB, FHKAM (Medicine)
YP Chu, MB, BS, FHKAM (Medicine)
${ }^{1}$ WT Wong, MB, ChB, MRCP
${ }^{2}$ PPK Lau, MB, ChB, FHKAM (Medicine)
${ }^{3}$ HY Wong, MB, BS, FHKAM (Medicine)
${ }^{1}$ KK Lau, MB, BS, FHKAM (Medicine)
Department of Medicine and Geriatrics, Princess Margaret Hospital, Laichikok, Hong Kong
2 Department of Rehabilitation, Kowloon Hospital, Argyle Street, Hong Kong
${ }^{3}$ Department of Medicine, Queen Elizabeth Hospital, Jordan, Hong Kong
* Corresponding author: keison722@hotmail.com

\section{New knowledge added by this study \\ Warfarin-associated intracerebral haemorrhage $(\mathrm{ICH})$ carries a high mortality. \\ - The reversal of coagulopathy after warfarin-associated ICH was often incomplete. \\ - Given the high mortality after warfarin-associated ICH, newer oral anticoagulants may be a safer alternative in patients with a high risk of cerebral bleeding. As a class of drugs, they are associated with fewer ICHs.}

\section{Introduction}

Atrial fibrillation (AF) is associated with an increased risk of stroke or systemic thromboembolism. Approximately $5 \%$ of AF patients develop stroke or other embolic events each year. ${ }^{1}$ Anticoagulation with warfarin, a vitamin $\mathrm{K}$ antagonist, reduces stroke risk in AF patients by $64 \%{ }^{2}$ It has been the drug of choice for many years in both primary and secondary stroke prevention in AF. Unfortunately, anticoagulation increases the risk of bleeding, and intracerebral haemorrhage (ICH) has been the most life-threatening bleeding complication of concern. This study aimed to compare the clinical features and neurological outcomes of ICH in warfarinised 


\section{心房顫動患者在服用華法林期間出現腦出血引致 嚴重神經功能缺損：匹配病例研究的結論 \\ 方文麒、盛斌、朱炎培、王華鈦、劉培基、王曉怡、劉國光}

引言：随着人口老化，心房顫動患者對抗凝血治療的需求不斷增加， 使抗凝血治療相關的腦出血也變得越來越普遍。本研究針對因心房顫 動而服用華法林的腦出血患者與無服用華法林的腦出血患者作比較, 探討他們臨床特徵和神經功能結果。

方法：研究對象為2006年1月1日至2011年12月31日期間到香港三間 醫院的腦出血患者。採用回顧性匹配病例系列方法, 把腦出血患者分 為兩組：因心房顫動服用華法林的患者（ICH-W組）和沒有服用華 法林的患者（ICH-C組），並以 $1 ： 1$ 的比例匹配患者年齡和性別。比 較兩組的臨床特徵和神經結果, 並研究抗凝血治療對血腫塊大小的影 響。

結果：ICH-W組有 114 名患者, 平均年齡75歲。兩組的腦出血評分中 位數均為 2 。 ICH-W組比 ICH-C組的腦出血量較高 $(12.9 \mathrm{~mL}$ 比 10.5 $\mathrm{mL}$ ），但未達統計學意義；6個月的改良Rankin量表評分（mRS） 中位數和有良好恢復的患者比例（即 $\mathrm{mRS} \leq 3$ ）相若。 ICH-W組的住 院死亡率 $(51.8 \%$ 比 $36.0 \% ; \mathrm{P}=0.02)$ 以及6個月死亡率 $(60.5 \%$ 比 $43.0 \% ; \mathrm{P}=0.01$ ) 均比ICH-C組高。ICH-W組中有 $60 \%$ 患者的入院 國際標準化比率 (INR) 在腦出血的治療範圍內, 另 $14 \%$ 患者的入院 INR未達治療水平。入院INR與腦出血量或神經功能的結果無關。

結論：與沒有服用華法林的腦出血患者比較, 服用華法林的房顫患者 發生腦出血時有較高的中風死亡率。

AF patients with those in non-warfarinised patients.

\section{Methods}

This was a retrospective matched case series of consecutive patients with first acute $\mathrm{ICH}$ admitted to the medical unit of three tertiary hospitals in Hong Kong-Princess Margaret Hospital (PMH) and Caritas Medical Centre (CMC) in Kowloon West, and Queen Elizabeth Hospital (QEH) in Kowloon Central-from 1 January 2006 to 31 December 2011. The three hospitals cover about one quarter of the 7 million population in Hong Kong. It is a general practice in Hong Kong that patients with acute stroke symptoms are admitted to the medical unit (to acute stroke unit first, and to general medical ward if acute stroke unit is full) for further management, with computed tomography (CT) brain scans done within 24 hours of admission. If $\mathrm{ICH}$ is identified, a neurosurgeon will be consulted for assessment. Therefore $\mathrm{ICH}$ patients in the medical unit are a good indication of the general $\mathrm{ICH}$ population.

We searched our electronic database for all patients aged 18 years or above who developed first $\mathrm{ICH}$ in the presence of anticoagulation with warfarin for non-valvular AF (ICH-W group) from the three hospitals, and matched them with a comparison group (ICH-C group) without taking warfarin at a 1:1 ratio for age $( \pm 1$ year), gender, and admission year. The comparison group comprised patients from the medical unit of PMH (principal study centre) who had a first episode of $\mathrm{ICH}$ without anticoagulation, regardless of any AF. Patients with isolated subdural, subarachnoid, or intraventricular haemorrhage were excluded. We retrieved and compared the data regarding neurological impairment and investigation findings, estimated the $\mathrm{ICH}$ volume on $\mathrm{CT}$ through the $\mathrm{ABC} / 2$ method, and calculated the ICH score. ${ }^{3,4}$ Hospital mortality and 6-month modified Rankin Scale score (mRS, 0-6) were selected as primary and secondary outcomes, respectively. We used independent sample $t$ test and Mann-Whitney $U$ test for univariate comparisons of continuous variables (Glasgow Coma Scale score, $\mathrm{ICH}$ score, $\mathrm{ICH}$ volume, mRS), and Chi squared test for categorical variables. Descriptive summary statistics, where appropriate, are presented as mean (range) or median (interquartile range [IQR]). All calculations were two-end conducted at a 0.05 level of significance. The study was approved by the local ethics committee (KW/EX-12-057[52-06]), with the requirement of patient informed consent waived because of its retrospective nature.

\section{Results}

Overall, 114 patients were identified and recruited in the ICH-W group (37 from PMH, 8 from CMC, and 69 from QEH; Table 1) with a mean age of 75 years (range, 47-92 years) and a slight male predominance $(56.1 \%)$. The same number of patients matched for age $( \pm 1$ year) and gender were grouped for comparison (ICH-C). Both $\mathrm{ICH}-\mathrm{W}$ and $\mathrm{ICH}-\mathrm{C}$ groups had a median $\mathrm{ICH}$ score of 2 , but there was a trend for higher $\mathrm{ICH}$ volume in $\mathrm{ICH}-\mathrm{W}$ patients than in $\mathrm{ICH}-\mathrm{C}$ patients $(12.9 \mathrm{~mL}$ vs $10.5 \mathrm{~mL})$ although it did not reach statistical significance. A total of 59 patients in ICH-W died during the same admission, and a further 10 patients had died by 6 months. The ICH-W patients had significantly higher hospital mortality (51.8\% vs $36.0 \%$; Chi squared test, $\mathrm{P}=0.02$ ) and 6 -month mortality (60.5\% vs $43.0 \%$; Chi squared test, $\mathrm{P}=0.01)$ than the $\mathrm{ICH}-\mathrm{C}$ patients. The median $\mathrm{mRS}$ and the proportion with good recovery (mRS $\leq 3)$ at 6 months were comparable for the two groups (Table 1).

Two patients in the ICH-W group died before determination of international normalised ratio (INR). For the remaining 112, the admission INR was $<2.0$ in 16 (14.3\%) patients, $2.0-3.0$ in 66 (58.9\%) patients, and $>3.0$ in $30(26.8 \%)$ patients. The INR was re-checked in 85 patients after 12 hours and in 72 patients after 24 hours. The median INR was corrected from 2.6 (IQR, 2.1-3.1) to 1.4 (IQR, 1.21.7 ) at 12 hours post-event, and 1.3 (IQR, 1.1-1.5) at 24 hours post-event. The corresponding percentage of INR $>1.5$ was $96.4 \%(108 / 112)$ on admission, $35.3 \%(30 / 85)$ at 12 hours, and $22.2 \%(16 / 72)$ at 24 hours. No association was found between admission 
INR and ICH volume, hospital mortality, or 6-month mRS (Spearman's rank correlation coefficient). Regarding the warfarin reversal strategies, $\mathrm{QEH}$ had an in-patient protocol whereas $\mathrm{PMH}$ and CMC did not. Nevertheless, there was no significant difference in mortality rate among the three hospitals-hospital mortality/6-month mortality in PMH 18 (48.6\%)/20 (54.1\%), in CMC five (62.5\%)/ six (75.0\%), and in QEH $36(52.2 \%) / 43$ (62.3\%). Prothrombin complex concentrate (PCC), fresh frozen plasma (FFP), vitamin K1 (VitK1), factor VII, and transamin were used alone or in combination in our ICH-W patients. Their frequency was as follows: FFP alone $(69,60.5 \%)$, FFP + VitK1 (17, 14.9\%), FFP + PCC $(9,7.9 \%)$, PCC alone $(3,2.6 \%)$, transamin alone (3, 2.6\%), VitK1 alone (2, 1.8\%), FFP + transamin (1, $0.9 \%)$, and FFP + factor VII (1, 0.9\%). Nine (7.9\%) patients received no treatment-two patients died before admission INR was available, three patients died soon after admission INR was available, three patients had admission INR of $<1.5$, and one patient was on warfarin and aspirin for ischaemic heart disease. The high variation in anticoagulation reversal strategy made it impossible for any valid comparison.

\section{Discussion}

Cardioembolic stroke related to AF carries significant morbidity, yet anticoagulation is not without risk. How to prevent stroke and at the same time minimise bleeding complications has always been a dilemma for physicians and patients. Risk assessment tools (eg $\mathrm{CHA}_{2} \mathrm{DS}_{2}$-VASc and HAS-BLED score, for assessment of thromboembolic and bleeding risk, respectively) have been developed to assist the decision making. ${ }^{5,6}$ It is important for clinicians to exercise individualised medical practice, however. In a recently published observation study on a large hospital cohort of Chinese AF patients from Hong Kong, the investigators found that the stroke risk in Chinese AF patients was higher than that in Caucasians at a given $\mathrm{CHA}_{2} \mathrm{DS}_{2}$-VASc score, and that excessive risk was more prominent in the low-risk group from $\mathrm{CHA}_{2} \mathrm{DS}_{2}$-VASc. ${ }^{7}$ At the same time, the $\mathrm{ICH}$ incidence in Chinese AF patients taking warfarin was also higher than that in Caucasians. ${ }^{8}$ These observations really drive clinicians towards a better anticoagulation strategy for Chinese AF patients.

Unfortunately $\mathrm{ICH}$ remains a significant threat even with very careful patient selection and treatment monitoring. Up to $25 \%$ of ICH can be associated with anticoagulant usage, and the rate is still increasing given the higher utilisation of anticoagulation in ageing populations with rising AF prevalence., ${ }^{9,10}$ Several features of warfarin-associated $\mathrm{ICH}$ in our patients deserve further elaboration, as listed below.

First, we found a large proportion (73.2\%) of warfarin-associated $\mathrm{ICH}$ occurred when the INR
TABLE I. Clinical characteristics and neurological outcomes

\begin{tabular}{lccc}
\hline Variable & \multicolumn{2}{c}{ Median, median (IQR), or No. (\%) } & P value \\
\cline { 2 - 3 } & ICH-W group (n=114) & ICH-C group (n=114) & \\
\hline GCS & $14(8-15)$ & $11(7-15)$ & 0.53 \\
ICH score & 2 & 2 & 0.45 \\
ICH volume (mL) & 12.9 & 10.5 & 0.34 \\
Hospital mortality & $59(51.8)$ & $41(36.0)$ & 0.02 \\
mRS (at 6 months) & 6 & 5 & 0.63 \\
mRS $\leq 3$ (at 6 months) & $22(19.3)$ & $28(24.6)$ & 0.38 \\
Mortality (at 6 months) & $69(60.5)$ & $49(43.0)$ & 0.01 \\
\hline
\end{tabular}

Abbreviations: GCS = Glasgow Coma Scale score; ICH = intracerebral haemorrhage; $\mathrm{ICH}-\mathrm{C}=$ patients not taking warfarin for atrial fibrillation showing intracerebral haemorrhage; $\mathrm{ICH}-\mathrm{W}=$ patients taking warfarin for atrial fibrillation showing intracerebral haemorrhage; IQR = interquartile range; $\mathrm{mRS}$ = modified Rankin Scale score

was within or even below the therapeutic range (INR $\leq 3.0$ ). Our findings were supported by a similar observation from another prospective study in which $68 \%$ of warfarin-associated ICH occurred at INR of $\leq 3.0{ }^{11}$ This shows that bleeding is increased even with an INR within the therapeutic range. Moreover, those ICH-W patients with a subtherapeutic INR reaffirm the high intrinsic $\mathrm{ICH}$ risk in AF patients who are old with multiple co-morbidities.

Second, we did not find any correlation between initial $\mathrm{ICH}$ volume and admission INR. The initial ICH volume in warfarinised and nonwarfarinised patients was not significantly different. This is consistent with the results from some other studies..$^{9,12,13}$ In contrast, Cucchiara et $\mathrm{al}^{14}$ reported larger haematoma volume in anticoagulantassociated $\mathrm{ICH}$ than spontaneous $\mathrm{ICH}$, whereas Flaherty et $\mathrm{al}^{15}$ reported larger initial haematoma volume if admission INR was $>3.0$. It is reasonable to suppose that coagulopathy would have an impact on haematoma volume, but is difficult to confirm in clinical studies because it is hard to control other covariates that affect haematoma size. The relatively small number of subjects in the warfarin-associated $\mathrm{ICH}$ group is often underpowered to reach any solid conclusion. Nonetheless, other studies did show that warfarin use was a known predictor of haematoma expansion, and haematoma expansion an independent determinant of neurological outcomes in spontaneous ICH. ${ }^{12,14,16}$ All the consensus guidelines agree that coagulopathy should be reversed as soon as possible in warfarin-associated $\mathrm{ICH}$.

Third, both the hospital and 6-month mortalities in our ICH-W patients were significantly higher than those in ICH-C patients (Table 1). This observation is highly consistent with other reports in which warfarin-associated $\mathrm{ICH}$ had higher mortality than patients without taking warfarin (Table 2). ${ }^{9,11-15,17-20}$ Our study adopted a matched case series design in order to eliminate the effect of age, 
TABLE 2. Effect of warfarin on mortality and initial ICH volume in different studies

\begin{tabular}{|c|c|c|c|c|c|}
\hline & Present study & Rosand et al, 2004 ${ }^{11}$ & Flibotte et al, $2004^{12}$ & Flaherty et al, $2006^{17}$ & Zubkov et al, $2008^{18}$ \\
\hline Study design & $\begin{array}{l}\text { Retrospective, } \\
\text { matched case series }\end{array}$ & Prospective, cohort & Prospective, cohort & $\begin{array}{l}\text { Retrospective, case- } \\
\text { control }\end{array}$ & $\begin{array}{l}\text { Retrospective, case } \\
\text { series }\end{array}$ \\
\hline No. of subjects & $\begin{array}{l}\text { Warfarin, } 114 \\
\text { Control, } 114\end{array}$ & $\begin{array}{l}\text { Warfarin, } 102 \\
\text { Control, } 333\end{array}$ & $\begin{array}{l}\text { Warfarin, } 42 \\
\text { Control, } 141\end{array}$ & $\begin{array}{l}\text { Anticoagulant, } 190 \\
\text { Control, } 851\end{array}$ & Warfarin, 88 \\
\hline $\begin{array}{l}\text { Mean age in years } \\
\text { (warfarin / non-warfarin) }\end{array}$ & $74.9 / 74.9$ & $75.7 / 74.0$ & 75.7 & $74.8 / 68.9$ & 76 \\
\hline INR in warfarin group & Median 2.6 & Not reported & Median 3.1 & Not reported & Median 3.2 \\
\hline $\begin{array}{l}\text { Initial ICH volume in } \\
\text { warfarin vs non-warfarin }\end{array}$ & $\begin{array}{l}\text { No significant } \\
\text { difference }\end{array}$ & Not reported & $\begin{array}{l}\text { No significant } \\
\text { difference; warfarin } \\
\text { associated with } \\
\text { haematoma expansion }\end{array}$ & Not reported & Not reported \\
\hline INR and ICH volume & No correlation & Not reported & Not reported & Not reported & Not reported \\
\hline $\begin{array}{l}\text { Mortality (warfarin vs non- } \\
\text { warfarin) }\end{array}$ & $\begin{array}{l}\text { Hospital: } 51.8 \% \text { vs } \\
36 \% ; 6-\text { month: } 60.5 \% \\
\text { vs } 43 \%\end{array}$ & $\begin{array}{l}\text { 3-Month: } 52.0 \% \text { vs } \\
25.8 \%\end{array}$ & Not reported & $\begin{array}{l}\text { 1-Day: } 33.2 \% \text { vs } \\
\text { 16.3\%; } 1 \text {-year: } 66.3 \% \\
\text { vs } 50.3 \%\end{array}$ & 7-Day: 39.8\% \\
\hline
\end{tabular}

Abbreviations: $\mathrm{ICH}=$ intracerebral haemorrhage; INR = international normalised ratio

and to minimise the age-related co-morbidities that are known predictors of poor neurological outcome from $\mathrm{ICH}$. As a result, our selected ICH-C patients were older and probably had more co-morbidities than the general $\mathrm{ICH}$ patients. This explained the higher-than-usual mortality and poor neurological outcomes in our ICH-C group compared with other studies. Nonetheless, AF-related co-morbidity could not be controlled in this design, and we believe our observed difference in mortality and neurological outcomes is a compound effect from AF and warfarin use in the ICH-W patients.

Currently, the optimal therapy for coagulopathy reversal in warfarin-associated major bleeding is unclear and recommendations of international guidelines are mainly derived from consensus opinions. Treatment options include FFP, VitK1, PCC, and recombinant factor VIIa, in different combinations. ${ }^{21}$ One of the three study hospitals (QEH) had an in-house protocol for warfarin reversal. The other two hospitals provide guidelines only. Because of the incomplete data collection from this retrospective study design, we were unable to analyse the haematoma growth and warfarin reversals. The mortality, however, did not differ among the three hospitals.

Since 2010, newer oral anticoagulants have become available and provide an alternative to warfarin in AF stroke prevention. The three new oral anticoagulants-dabigatran, rivaroxaban, and apixaban ${ }^{22-24}-$ might differ in efficacy, but the lower ICH rate compared with warfarin was a universal finding from their clinical trials, and is a class effect of these new agents. They should be considered in Chinese AF patients at a high risk of warfarinassociated $\mathrm{ICH}$.

\section{Limitations of study}

As a retrospective study, this study has several limitations. First, the methods and timing of warfarin reversal were not standardised and could have affected the neurological outcome. Second, there was no protocol for serial CT brain and serial INR monitoring to investigate the effect of coagulopathy reversal on haematoma expansion, and the effect of haematoma expansion on neurological outcome. Third, we were uncertain about compliance with the coagulopathy reversal protocol in QEH, and were unable to comment on whether the standardised protocol could improve ICH outcome. Moreover, $\mathrm{ICH}-\mathrm{W}$ patients were AF patients who had additional vascular risk factors (to justify the use of warfarin) that may not have been present in ICH-C patients. This difference could potentially affect the ICH outcome. Finally, other possible confounders such as smoking or alcohol use were not adjusted for in this retrospective study.

\section{Conclusion}

Warfarin-associated ICH in AF patients may be associated with higher stroke mortality. It could be a serious problem in Chinese AF patients who are known to have more warfarin-associated ICH.

\section{Declaration}

The authors declared no conflicts of interest in this study.

\section{References}

1. Wolf PA, Abbott RD, Kannel WB. Atrial fibrillation as an independent risk factor for stroke: the Framingham Study. Stroke 1991;22:983-8. 


\begin{tabular}{|c|c|c|c|c|c|}
\hline Cucchiara et al, $2008^{14}$ & Flaherty et al, $2008^{15}$ & Sheth et al, $2010^{13}$ & $\begin{array}{l}\text { Huhtakangas et al, } \\
2011^{19}\end{array}$ & $\begin{array}{l}\text { Horstmann et al, } \\
2013^{9}\end{array}$ & Seçil et al, $2014^{20}$ \\
\hline $\begin{array}{l}\text { Retrospective, nested } \\
\text { case-control }\end{array}$ & $\begin{array}{l}\text { Retrospective, case- } \\
\text { control }\end{array}$ & $\begin{array}{l}\text { Retrospective, nested } \\
\text { matched case-control }\end{array}$ & $\begin{array}{l}\text { Retrospective, case- } \\
\text { control }\end{array}$ & Prospective cohort & $\begin{array}{l}\text { Retrospective case } \\
\text { series }\end{array}$ \\
\hline $\begin{array}{l}\text { Anticoagulant, } 21 \\
\text { Control, } 282\end{array}$ & $\begin{array}{l}\text { Warfarin, } 51 \\
\text { Control, } 207\end{array}$ & $\begin{array}{l}\text { Warfarin, } 50 \\
\text { Control, } 50\end{array}$ & $\begin{array}{l}\text { Warfarin, } 182 \\
\text { Control, } 800\end{array}$ & $\begin{array}{l}\text { Anticoagulant, } 51 \\
\text { Control, } 155\end{array}$ & $\begin{array}{l}\text { Warfarin, } 3 \\
\text { Control, } 389\end{array}$ \\
\hline $75 / 65$ & 68.5 & Not reported & $74.4 / 67.9$ & $75 / 72$ & $64.4 / 61.0$ \\
\hline Median 2.0 & Median 2.7 & Median 3.2 & Mean 3.1 & Median 2.7 & Mean 4.78 \\
\hline $\begin{array}{l}\text { Large in oral anticoagulant } \\
\text { group; oral anticoagulant } \\
\text { associated with } \\
\text { haematoma expansion }\end{array}$ & Not reported & $\begin{array}{l}\text { No significant } \\
\text { difference }\end{array}$ & Not reported & $\begin{array}{l}\text { No significant } \\
\text { difference }\end{array}$ & Not reported \\
\hline Not reported & $\begin{array}{l}\text { INR > } 3 \text { had greater } \\
\text { haematoma volume }\end{array}$ & Not reported & Not reported & Not reported & Not reported \\
\hline Not reported & Not reported & Not reported & $\begin{array}{l}\text { 1-Year: } 64.8 \% \text { vs } \\
32.1 \%\end{array}$ & $\begin{array}{l}\text { 3-Month: } 45.1 \% \text { vs } \\
32.4 \%\end{array}$ & $65.6 \%$ vs $30.1 \%$ \\
\hline
\end{tabular}

2. Hart RG, Pearce LA, Aguilar MI. Meta-analysis: antithrombotic therapy to prevent stroke in patients who have nonvalvular atrial fibrillation. Ann Intern Med 2007;146:857-67.

3. Kothari RU, Brott T, Broderick JP, et al. The ABCs of measuring intracerebral hemorrhage volumes. Stroke 1996;27:1304-5.

4. Hemphill JC 3rd, Bonovich DC, Besmertis L, Manley GT, Johnston SC. The ICH score: a simple, reliable grading scale for intracerebral hemorrhage. Stroke 2001;32:891-7.

5. Lip GY, Nieuwlaat R, Pisters R, Lane DA, Crijns HJ. Refining clinical risk stratification for predicting stroke and thromboembolism in atrial fibrillation using a novel risk factor-based approach: the Euro heart survey on atrial fibrillation. Chest 2010;137:263-72.

6. Pisters R, Lane DA, Nieuwlaat R, de Vos CB, Crijns HJ, Lip GY. A novel user-friendly score (HAS-BLED) to assess 1-year risk of major bleeding in patients with atrial fibrillation: the Euro heart survey. Chest 2010;138:1093-100.

7. Siu CW. One more "C" for CHA2DS2-VASc score? J Am Coll Cardiol 2015;65:1602-3.

8. Siu CW, Lip GY, Lam KF, Tse HF. Risk of stroke and intracranial hemorrhage in 9727 Chinese with atrial fibrillation in Hong Kong. Heart Rhythm 2014;11:1401-8.

9. Horstmann S, Rizos T, Lauseker $M$, et al. Intracerebral hemorrhage during anticoagulation with vitamin $\mathrm{K}$ antagonists: a consecutive observational study. J Neurol 2013;260:2046-51.

10. Flaherty ML, Kissela B, Woo D, et al. The increasing incidence of anticoagulant-associated intracerebral hemorrhage. Neurology 2007;68:116-21.

11. Rosand J, Eckman MH, Knudsen KA, Singer DE, Greenberg SM. The effect of warfarin and intensity of anticoagulation on outcome of intracerebral hemorrhage. Arch Intern Med 2004;164:880-4.

12. Flibotte JJ, Hagan N, O’Donnell J, Greenberg SM, Rosand J. Warfarin, hematoma expansion, and outcome of intracerebral hemorrhage. Neurology 2004;63:1059-64.

13. Sheth KN, Cushing TA, Wendell L, et al. Comparison of hematoma shape and volume estimates in warfarin versus non-warfarin-related intracerebral hemorrhage. Neurocrit Care 2010;12:30-4.

14. Cucchiara B, Messe S, Sansing L, Kasner S, Lyden P, CHANT Investigators. Hematoma growth in oral anticoagulant related intracerebral hemorrhage. Stroke 2008;39:2993-6.

15. Flaherty ML, Tao H, Haverbusch M, et al. Warfarin use leads to larger intracerebral hematomas. Neurology 2008;71:1084-9.

16. Davis SM, Broderick J, Hennerici M, et al. Hematoma growth is a determinant of mortality and poor outcome after intracerebral hemorrhage. Neurology 2006;66:1175-81.

17. Flaherty ML, Haverbusch M, Sekar P, et al. Location and outcome of anticoagulant-associated intracerebral hemorrhage. Neurocrit Care 2006;5:197-201.

18. Zubkov AY, Mandrekar JN, Claassen DO, Manno EM, Wijdicks EF, Rabinstein AA. Predictors of outcome in warfarin-related intracerebral hemorrhage. Arch Neurol 2008;65:1320-5.

19. Huhtakangas J, Tetri S, Juvela S, Saloheimo P, Bode MK, Hillbom M. Effect of increased warfarin use on warfarinrelated cerebral hemorrhage: a longitudinal populationbased study. Stroke 2011;42:2431-5.

20. Seçil Y, Ciftçi Y, Tokuçoğlu F, Beckmann Y. Intracranial hemorrhages related with warfarin use and comparison of warfarin and acetylsalicylic acid. J Stroke Cerebrovasc Dis 2014;23:321-6.

21. Aguilar MI, Hart RG, Kase CS, et al. Treatment of warfarinassociated intracerebral hemorrhage: literature review and expert opinion. Mayo Clin Proc 2007;82:82-92.

22. Connolly SJ, Ezekowitz MD, Yusuf S, et al. Dabigatran versus warfarin in patients with atrial fibrillation. $\mathrm{N}$ Engl J Med 2009;361:1139-51.

23. Patel MR, Mahaffey KW, Garg J, et al. Rivaroxaban versus warfarin in nonvalvular atrial fibrillation. $\mathrm{N}$ Engl J Med 2011;365:883-91.

24. Granger CB, Alexander JH, McMurray JJ, et al. Apixaban versus warfarin in patients with atrial fibrillation. N Engl J Med 2011;365:981-92. 